\title{
COMPOSITION AND CLASSIFICATION OF CHROMITES IN THE FISKENESSET ANORTHOSITE COMPLEX
}

\author{
Martin Ghisler
}

Chromite compositions from about 30 different localities throughout the whole of the Fiskenæsset region were studied in detail with the microprobe. The samples were selected on the basis of $\mathrm{Cr}$ - $\mathrm{Fe} \mathrm{X}$-ray fluorescence analyses on chromite concentrates of 183 samples (Ghisler, in press) and after examination of a large number of polished sections. They are considered as presenting the complete composition range within the area. For a detailed presentation of methods and results the reader is referred to Ghisler (in press). Here only the main results are given of the composition of chromite in terms of the elements $\mathrm{Cr}, \mathrm{Al}, \mathrm{Fe}$ and $\mathrm{Mg}$, which are necessary for their classification. Ten grains were assayed within each polished section, based upon measurements at several points in each grain. The results presented below are thus based upon the composition of about 300 grains, with a total of about 1000 point analyses.

Histograms of fig. 29 show the composition of 33 chromite samples from the anorthosite unit. The $\mathrm{Cr}_{2} \mathrm{O}_{3}$ contents vary from $25.8 \%$ to $44.1 \%$ (weight \%) with an average of $35.1 \%$ $\mathrm{Cr}_{2} \mathrm{O}_{3}$. The $\mathrm{Cr}$ content is rather constant throughout the area with $87 \%$ of the samples between $30.1 \%$ and $39.0 \% \quad \mathrm{Cr}_{2} \mathrm{O}_{3}$. The $\mathrm{Al}_{2} \mathrm{O}_{3}$ contents are much more widespread ranging from $4.9 \%$ to $25.8 \%$ with an average of $18.6 \% \mathrm{Al}_{2} \mathrm{O}_{3}$. The $\mathrm{Fe}_{2} \mathrm{O}_{3}$ content (calculated from total iron, based on the assumption that the ratio $\mathrm{RO}: \mathrm{R}_{2} \mathrm{O}_{3}$ components is equal to 1 ), varies considerably from $6.7 \%$ to $32.6 \%$ with an average of $13.4 \% \mathrm{Fe}_{2} \mathrm{O}_{3}$. The RO components are strongly dominated by iron FeO lying constantly around the mean of $29.4 \%$, ranging from $25.5 \%$ to $33.2 \% \mathrm{FeO}$. The $\mathrm{MgO}$ content is very low throughout the area with an average of $3.5 \%$, ranging from $0.3 \%$ to a maximum of $6.5 \% \mathrm{MgO}$.

The bulk composition of two chromites analysed from ultramafic host rocks are somewhat richer in $\mathrm{Al}$ and $\mathrm{Mg}$, but fall in approximately the same field of composition. These chromite occurrences are of little importance quantitatively compared to the chromite deposits associated with anorthosite.

Graphical presentation of composition of minerals belonging to the spinel group is difficult as so many elements may enter the lattice. For the relative importance of the main elements occurring several graphical methods have been proposed. Stevens (1944) describes the spinel triangular prism of composition for the major elements $\mathrm{Cr}, \mathrm{Al}, \mathrm{Fe}$ and $\mathrm{Mg}$, but for comparative purposes triangular diagrams are more useful. The molecular ratio of the $\mathrm{RO}$ and $\mathrm{R}_{2} \mathrm{O}_{3}$ components are calculated, and the resulting formula according to Thayer's (1946) method are found. The different norm compositions of the chromites are plotted in a chromite - spinel - magnetite triangular diagram (fig. 30 ).

For the chromites originating from anorthosites the majority of the values fall according to Stevens' (1944) classification into the field of aluminian chromite (24 samples), a minor 

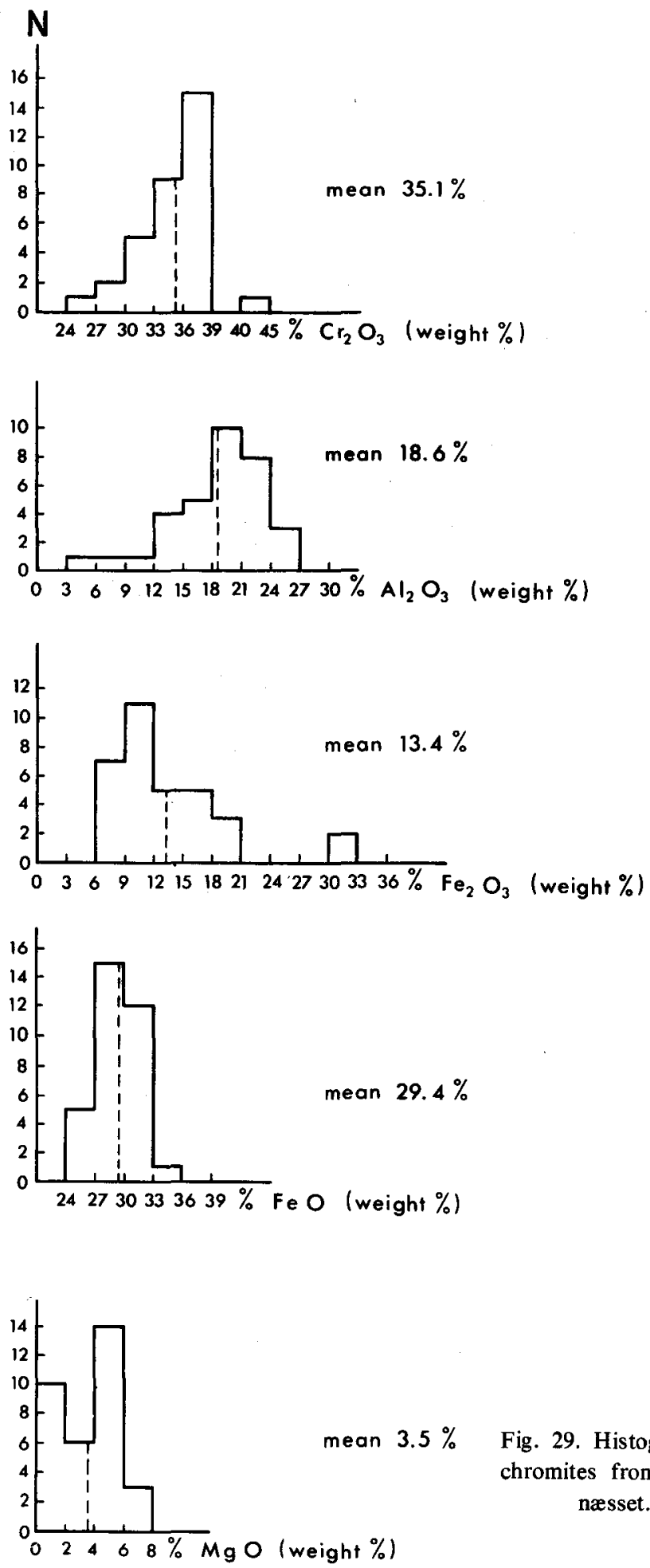

Fig. 29. Histograms showing composition of 33 chromites from anorthositic host rocks, Fiskenæsset. $\mathbf{N}=$ number of samples. 


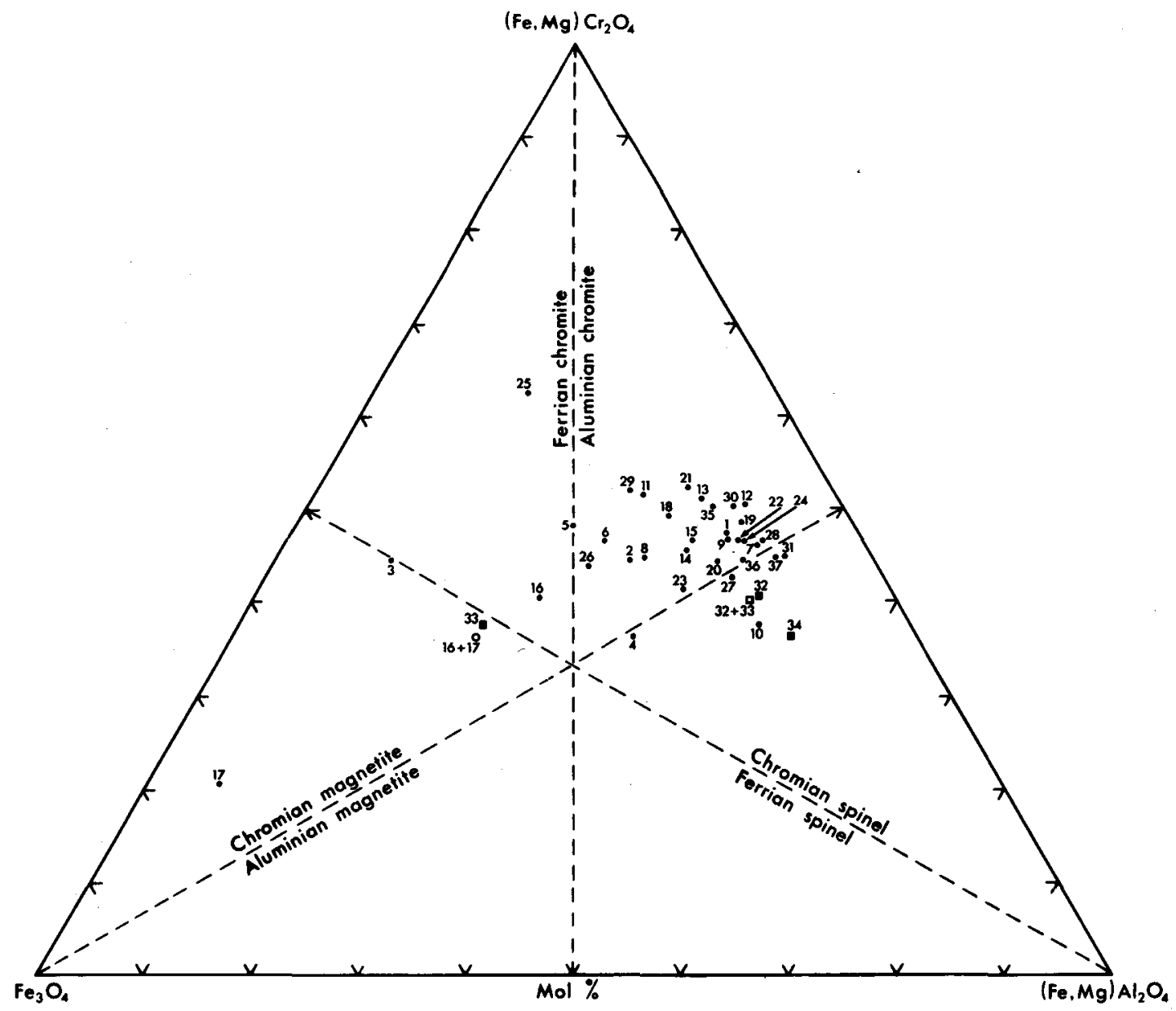

Fig. 30. Chromite-spinel-magnetite triangular diagram, showing the norm composition of the Fiskenæsset chromites $\left(\mathrm{R}_{2} \mathrm{O}_{3}\right.$ components).

group into the field of chromian spinel (5 samples), whereas chromian magnetites and ferrian chromites are represented by three plots each. One sample consisted of two phases, the host ferrian chromite (no. 16) and an exsolved more iron rich chromian magnetite phase (no. 17). The bulk composition is indicated $16+17$.

The bulk composition of the two chromites from ultramafic rocks are both classified as chromian spinel (no. 34 and $32+33$ ). The latter consists of a chromian spinel host (no. 32) with exsolutions of chromian magnetite (no. 33).

The diagram (fig. 30) shows only the relative amounts of the $\mathrm{R}_{2} \mathrm{O}_{3}$ components. The $\mathrm{MgO} / \mathrm{FeO}+\mathrm{MgO}$ molecular ratios vary considerably, from $\mathrm{Mg}_{1} \mathrm{Fe}_{99}$ to $\mathrm{Mg}_{48} \mathrm{Fe}_{52}$. For the chromites originating from anorthosites the maximum $\mathrm{Mg}$ content corresponds to $\mathrm{Mg}_{31} \mathrm{Fe}_{69}$; the average of the 33 samples investigated (from anorthosites) may be expressed by the following formula: 


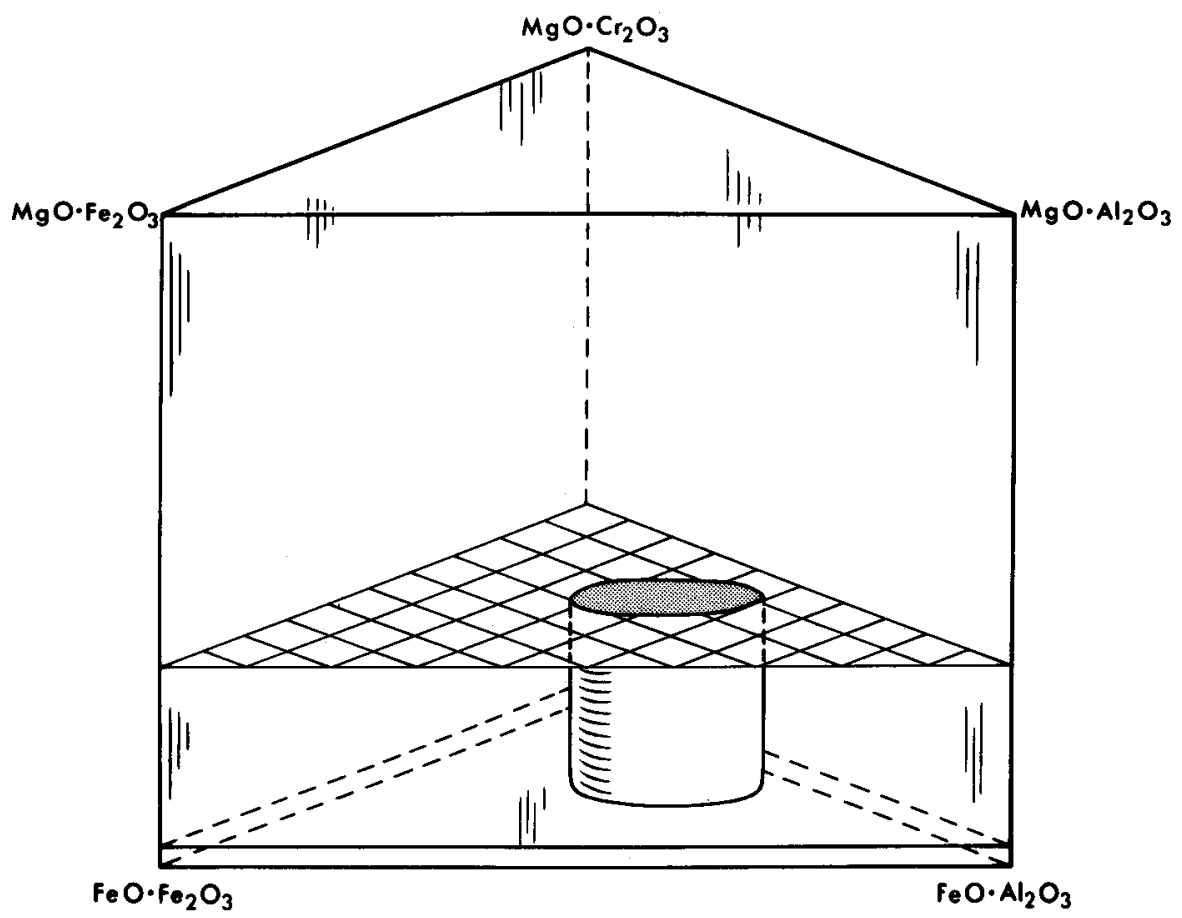

Fig. 31. Spinel triangular prism of composition, showing the position of the main portion of the Fiskenæsset chromites.

$\left(\mathrm{Fe}_{82} \mathrm{Mg}_{18}\right)\left(\mathrm{Cr}_{46} \mathrm{Al}_{37} \mathrm{Fe}_{17}\right)_{2} \mathrm{O}_{4}$

or in the means of norms:

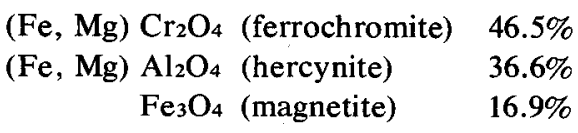

In fact the terms given represent the pure end members, which is not strictly correct in this case, but as Fe really dominates the RO group, these terms seem reasonable.

An attempt is made to illustrate the composition of the Fiskenæsset chromites from anorthosites in the triangular prism (fig. 31). Neglecting the few samples of strongly deviating composition, they fall within a cylinder at the lower part of the prism.

Recent detailed investigations have shown that the primary Fiskenæsset chromites partly recrystallised during several phases of folding and regional metamorphism (Ghisler, in press). The degree of recrystallisation varies from place to place and mainly depends upon the extent of stretching or flattening of each horizon. The recrystallised chromites may show distinctly lower contents of aluminium and magnesium and slightly lower $\mathrm{Cr}$ contents, whereas they are often considerably enriched in iron. The compositions of samples in fig. 30 accordingly only partly represent the primary chromites. The average composition of the pre-orogenic chromites corresponds to the formula:

$$
\left(\mathrm{Fe}_{75} \mathrm{Mg}_{25}\right)\left(\mathrm{Cr}_{47} \mathrm{Al}_{42} \mathrm{Fe}_{11}\right)_{2} \mathrm{O}_{4}
$$


The composition of the Fiskenæsset chromites indicates that they represent a significant new type among the major occurrences of this mineral throughout the world. Weiser (1966) investigated 214 chromite samples from 35 different deposits by microprobe. His results are shown in fig. 32 together with the results of the present investigation. The Fiskenæsset chromites (30 samples) plot into an area where none of Weiser's representatives are found. Only very few published chromite analyses plot within this field (Weiser, 1966, p. 62). Examples are chromites from the Red Mountain deposits, Kenai Peninsula, Alaska (Stevens, 1944) which occur in peridotite and have been contact metasomatosed by an augite-hornblende dyke (Guild, 1942). Altered chromites from Barramia, Egypt, (Amin, 1948) show similar $\mathrm{R}_{2} \mathrm{O}_{3}$ norm composition, but $\mathrm{MgO}$ here completely dominates the RO components. Further examples are known from Maryland (Shannon, 1926) and from Wankur, India. The latter, a small folded chromite lens in " a country rock of hornblende schist and gneiss" of Precambrian age (Sarma, 1960), is of very similar composition to the Fiskenæsset chromites. But all these deposits are either small and not very well known or completely different from the Fiskenæsset one with respect to host rock

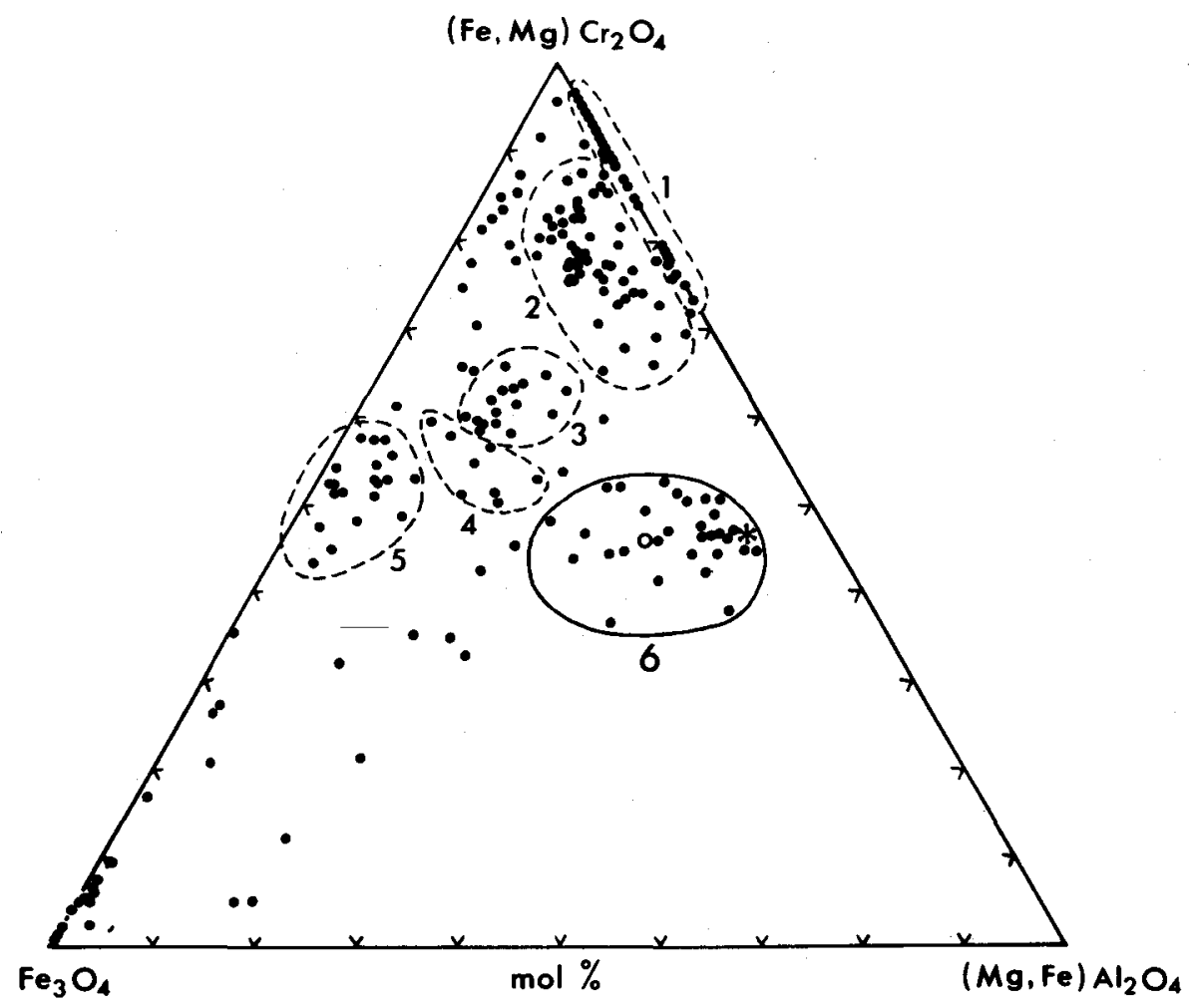

Fig. 32. Provinces of chromite deposits, based on the present analyses from the Fiskenæsset region and on microprobe investigations by Weiser (1966).

1. Southern Europe and Asia. 2. Bushveld Complex and Great Dyke. 3. Chromites from Bushveld Anorthosites. 4. Kemi (Finland). 5. Western Norway. 6. Fiskenæsset. $\star$ Sittampundi. $O$ average Fiskenæsset chromites. 
relations. A few chromite samples from the Anorthosite Series of the Bushveld complex (Cameron, 1964) show comparable compositions, but from fig. 32 it is seen that chromites from this series forms a special field (field 3) that does not overlap the Fiskenæsset compositional field.

The only very similar chromite from a deposit of major size is represented by one single assay of chromite from the Sittampundi complex, Madras India (Subramaniam, 1956, p. 354), which plots (fig. 32) within the Fiskenæsset field of composition, and is expressed by the formula:

$$
\left(\mathrm{Fe}_{66}, \mathrm{Mg}_{34}\right)\left(\mathrm{Cr}_{47} \mathrm{Al}_{45} \mathrm{Fe}_{8}\right)_{2} \mathrm{O}_{4}
$$

It is seen that the $\mathrm{R}_{2} \mathrm{O}_{3}$ values are nearly identical with the composition of the primary Fiskenæsset chromites, whereas the Sittampundi one shows a little higher $\mathrm{MgO}$ content.

The Fiskenæsset chromite deposits occur as persistent stratigraphic horizons in anorthosite, traceable along strike for more than $200 \mathrm{~km}$ covering an area of $4000 \mathrm{~km}^{2}$. They are thus typical stratiform type deposits, which however, show only weak affinities in chemistry to other major stratiform chromites (Irvine, 1967). The Fiskenæsset chromites are relatively rich in aluminium and iron and poor in chromium and magnesium. The genetic and chemical aspects of the Fiskenæsset chromite deposits are so characteristic and different from other major chromite deposits in the world that it seems reasonable to introduce the term 'Fiskenæsset type', as suggested by Ghisler (1970).

\section{References}

Amin, M. S. 1948: Origin and alteration of chromites from Egypt. Econ. Geol. 43, 133-153.

Cameron, E. N. 1964: Chromite deposits of the eastern part of the Bushveld Complex. In Haughton,

S. H. (edit.) The geology of some ore deposits in Southern Africa. 2, 131-168. (Geol. Soc. S. Afr.).

Ghisler, M. 1970: Pre-metamorphic folded chromite deposits of stratiform type in the early Precambrian of West Greenland. Miner. Deposita 5, 223-236.

Ghisler, M. in press: The geology, mineralogy and geochemistry of the pre-orogenic Archaean stratiform chromite deposits at Fiskenæsset, West Greenland. Monogr. Ser. Mineral Deposits 14.

Guild, P. W. 1942: Chromite deposits of Kenai Peninsula, Alaska. Bull. U. S. geol. Surv. 931 G, 139-175.

Irvine, T. N. 1967: Chromian spinel as a petrogenetic indicator. Part 2. Petrologic applications. Can. J. Earth Sci. 4, 71-103.

Sarma, S. R. 1960: Chromite from Wankur. Neues Jb. Miner. Abh. 94, 905-907.

Shannon, E. V. 1926: Mineralogy of the chrome ores from Etchison, Montgomery Co. Md. Amer. Miner. 11, 16-20.

Stevens, R. E. 1944: Composition of some chromites of the western hemisphere. Amer. Miner. 29, $1-34$.

Subramaniam, A. P. 1956: Mineralogy and petrology of the Sittampundi Complex, Salem district, Madras State, India. Bull. geol. Soc. Am. 67, 317-390.

Thayer, T. P. 1946: Preliminary chemical correlation of chromite with the containing rocks. Econ. Geol. 41, 202-217.

Weiser, T. 1966: Geochemische Untersuchungen an Chromiten mit der Elektronenmikrosonde. Diss. München, $91 \mathrm{pp}$. 